\title{
PROLOGUE: THE DRUMS OF WAR
}

Crowds of people filled the heart of Boston, watching a thousand uniformed Irishmen parade away from the columned State House. After hostilities erupted at Fort Sumter, Americans rallied to defend nation, state, home, and sweetheart. Throngs of volunteers came forth to participate in what they expected would be a short, glorious war to either win the independence of the Confederacy or restore the Union. As the Ninth Massachusetts Volunteer Infantry left Boston that early summer's day, a spirit of patriotism and anticipation united those who had gathered.

One of the regiment's citizen soldiers was Patrick Robert Guiney, a young lawyer living near Boston with his beautiful wife and beloved infant daughter. His wife undoubtedly stood in the crowd, craning her neck for one last glimpse as he marched by, anxious at the prospect of time spent apart and the realization that he was destined for the seat of war. The Irishman soon came to appreciate that, contrary to early expectations, this conflict would be long and arduous. In a little over a year's time he rose in rank to command the Ninth Massachusetts and would eventually attain the honorary rank of brigadier general for gallant service in the field-along with a debilitating head wound that shattered his health and cost him an eye.

Guiney was born on January 15, 1835, in Parkstown, County Tipperary, an agricultural region of southern Ireland. He was baptized on April 27th, the son of James Guiney and his Scottish wife, born Judith Macrae or Magrath. At the age of seven, young Patrick joined his father to emigrate to the United States, forced out of Ireland due to troubles with a landlord. The boy and his father went first to New Brunswick, Canada, and then on to Maine. Here they experienced the discrimination some nativeborn Americans practiced against the Irish, when a hotel owner would not allow the Guineys to enter. Within a year, Patrick's 
mother and younger brother William joined them and the family settled in Portland, Maine. ${ }^{1}$

In boyhood, young Patrick endured much work and little youthful leisure. He walked three and a half miles to a rope factory where he performed monotonous labor as a wheel-boy. Upon reaching fourteen, Guiney became apprenticed to a machinist in the Essex Shop in Lawrence, Massachusetts, where he remained for half a year. A young man now, he returned to Portland for a three-year apprenticeship in the machine shop of the Portland Company. The labor did not appeal to the growing intellectual nature of the boy, and he attended grammar school in Portland with the dream of attending college someday. ${ }^{2}$ Furthermore, he later recounted a feeling of loneliness in his youth, writing that he "had no one to tell the secrets of my soul to. I say secrets, not

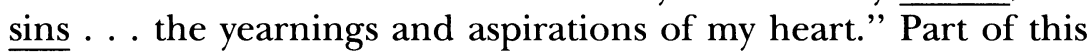
stemmed from the distance between the boy and his mother. Guiney's only daughter later recalled her as cold, stoic, and unsympathetic to the desires of her son. ${ }^{3}$

Guiney found release upon entering the College of the Holy Cross, a Jesuit school founded upon the hills of Worcester, Massachusetts. He entered the school October 20, 1854, joining a student body that numbered forty-two by year's end. He enjoyed his time spent at Holy Cross, later remembering fondly that "it was the Alma Mater of a few full minds and of many empty stomachs." However, his funds began to run low after a year. The president of the college, the Reverend Peter Blenkinsop, S.J., privately approached the young man and offered to arrange matters so that he could continue, but Guiney did not want to accept such charity. ${ }^{4}$

\footnotetext{
${ }^{1}$ Louise I. Guiney, "Patrick Robert Guiney," in The Holy Cross Purple, vol. 3, no. 1 (June 1896), 37-38. The Pilot, March 31, 1877. Grace Guiney to Fr. William Lucey, August 19, 1959. Birth Certificate for Patrick Robert Guiney, signed by William Breen, March 21, 1963, in Dinand Library Rare Book Room, College of the Holy Cross. James Bernard Cullen, ed., The Story of the Irish in Boston (Boston: James B. Cullen \& Company, 1889), p. 245.

${ }^{2}$ Louise I. Guiney, "Patrick Robert Guiney," 38. Sketch of "Our Candidate," General Guiney's Scrapbook, in Dinand Library Rare Book Room, College of the Holy Cross, p. 5. Hereafter cited as Guiney scrapbook.

${ }^{3}$ Patrick R. Guiney to Louise I. Guiney, December 5, 1876. Louise I. Guiney, "Patrick Robert Guiney," 38.

${ }^{4}$ Louise I. Guiney, "Patrick Robert Guiney," 38-39. Holy Cross Registration Book. Of the forty two students, two were from Canada, four from California,
} 
For a while, Guiney thought he would enjoy working in theater. He later recalled, "I was possessed with the idea of becoming an actor on the dramatic stage. I applied to a celebrated manager for a chance, and placing his hand tenderly on my head, he asked, 'do you think you can become a great actor?' I stammered that I did not know. 'Find that out first,' said he, 'for it is better to be a slave than a poor actor.' That interview cured me. I never went on the stage." 5

Instead, he went back to Portland to study law under Judge Charles Walton, who later served in the United States Congress and on the Maine State Supreme Court. ${ }^{6}$ Admitted to the bar on April 24, 1856, Guiney also put his eloquent writing to use as an assistant editor for the Lewiston Advocate in Maine. In September 1858 he relocated to Boston, where he served as a lawyer and wrote articles for the Boston Times. Although not much is known of their courtship, Guiney fell deeply in love with and married Jeannette Margaret Doyle on January 8, 1859, in the old Cathedral in Boston. She was a relative of the Right Reverend James Doyle, Bishop of Kildare and Lighlin. The Guineys quickly established residency in Roxbury, an independent town outside Boston at that time. ${ }^{7}$

Guiney became involved in public affairs and won election in 1859 to serve on the Common Council of Roxbury. On March 22, 1860, Guiney joined the Irish Charitable Society of Boston, an organization founded in 1737 by Bostonians of Irish ancestry. ${ }^{8}$ By the late 1850s the organization had become a "wining and dining club" for middle- and upper-class Irish. While it still provided small donations to Irish families in need, a sizeable portion of the society's budget went to fund its yearly St. Patrick's Day celebration at the posh Parker House, where it also held its quarterly

and two from Cuba-a surprising geographic assortment. Between January and June 1855 another ten students arrived.

${ }^{5}$ Patrick R. Guiney to Louise I. Guiney, March 8, 1877.

${ }^{6}$ Louise I. Guiney, "Patrick Robert Guiney," 39. United States Congress, Biographical Directory of the American Congress 1774-1927 (United States Government Printing Office, 1928), p. 1664. Walton served as a Republican in Congress from March 4, 1861 to May 26, 1862, when he accepted appointment as an associate justice on the state supreme court, a position he held for the next 25 years.

${ }^{7}$ Louise I. Guiney, "Patrick Robert Guiney," 39. The Pilot, March 31, 1877. Patrick R. Guiney Pension Record, National Archives, Washington, D.C. The Catholic News, August 2, 1930.

${ }^{8}$ Notes of Rev. William Lucey, S.J., Dinand Library Rare Book Room, College of the Holy Cross. 
meetings. ${ }^{9}$ Meanwhile, the young couple began a family. Their first-born son died in infancy, but Louise Imogen Guiney, born in Roxbury on January 7, 1861, grew up to become an eminent poet.

When the Civil War broke out, loyalty to his adopted state and country welled up in Guiney. In its time of need, he joined in defending the Union he had grown to cherish. Over the course of his service, Guiney wrote a series of beautiful letters to his wife. They run from June 4, 1861 to April 7, 1864 and discuss all aspects of life in the regiment and army, from training to combat duty, from camp under a starry sky to receiving absolution from the regimental chaplain before going into battle. In reading Guiney's words, one can have a fuller appreciation of what motivated civilians to volunteer to fight a war and of the privations they suffered in service to their country. Furthermore, the personality of an Irish Catholic soldier shines through, and Guiney's intense love for his wife and infant child, anxiety for the victorious conclusion of the war, and the burdens of leadership are common themes in his writing.

Above all, Guiney's political views comprise his most interesting aspect, as they set him apart from the majority of his Irish-American comrades. In several episodes, Guiney experienced opposition motivated by animosity at his divergence from the political tenets traditionally held by most Boston Irish. Originally a Democrat, like virtually all his countrymen, Guiney's later support for Lincoln, Republicanism, and the abolition of slavery created great tension between Guiney and several of his officers and even in the Boston community. Guiney often wrote of these difficulties, which became a major theme of his correspondence.

In his first surviving letter Guiney missed Jennie and Louise and expressed misgivings in parting with his family, fearing that perhaps he was too rash in enlisting. Throughout the war he agonized over their financial security and general well-being, yet honor and belief in the cause for which he fought kept him from resigning. He wrote, "the cause in which we are enlisted is truly a good and grand one-one that will entitle those who labor in the

\footnotetext{
${ }^{9}$ Oscar Handlin, Boston's Immigrants 1790-1880: A Study in Acculturation (Cambridge: Belknap Press of Harvard University, rev. and enl. ed. 1979), pp. 155, 160. Cullen, The Story of the Irish in Boston, pp. 40-41.
} 
achievement of its success to the gratitude and remembrance of the present, as well as of unborn generations-one that of itself compensates by its sublimity and goodness for all which may be sacrificed in its defense." 10

Despite longing to be reunited with his family, Guiney displayed an early enthusiasm for service and constantly reassured his wife that he would survive the war, that fortune would smile upon him. He acted as a typical soldier, reading a great deal to pass the time in camp, lonely without his wife, and waiting for constant letters from her. Overall, his greatest wish was for a rapid, victorious conclusion to the war and for his awaited homecoming.

Guiney also wrote about issues in his regiment and army and expressed many fascinating and astute opinions on military operations and high ranking-officers. He had critical assessments of the Ninth's Colonel Thomas Cass and Lieutenant Colonel Cromwell Rowell and scorned some officers who joined not to fight but to loaf. The letters describe the rivalries, ambitions, and schemes men attempted in an effort to advance in this, and probably all other, units. Guiney was a man of action who constantly desired vigorous, goal-directed activity. Even as Major General George B. McClellan's popularity peaked, Guiney criticized his slowness and realized that, despite his intelligence, McClellan did not have the "Genius" to conduct the war. Instead, Guiney wanted to push the Rebels, defeat them in battle, and end the war once and for all; he became exasperated at lost opportunities and unnecessary defeats. Furthermore, Guiney displayed an astute sense of how the war should be fought; while others called for a drive to capture Richmond, he saw the destruction of the Confederate army as the real Federal objective. Similarly, Guiney mirrored Lincoln's sentiment that Pennsylvanian George Meade would fight well in his own state during the Gettysburg campaign and believed that the entire Army of the Potomac would be inspired to shatter the Confederate invasion of a loyal Union state.

Guiney's letters are all the more illuminating and important in that they were written by a man very different from those he commanded. Beneath his seemingly smooth rise from first lieutenant to colonel, tension with several of his officers and with the

\footnotetext{
${ }^{10}$ Patrick R. Guiney to Jennie Guiney, Arlington Heights, Va., July 31, 1861.
} 
Boston Irish community plagued Guiney's tenure in command. Most Irish-Americans living in Boston at that time were poorly educated laborers living in slums. They became staunch Democrats with tremendous hostility toward Lincoln, Republicanism, and the blacks whose cause abolitionists promoted. Guiney, by contrast, was an educated lawyer, living in a Boston suburb, who came to support the Lincoln administration and liberation of blacks from the shackles of slavery. Not content to remain silent with his liberal views, Guiney professed his beliefs in word and deed, and made clear his political stance and individuality of thought. The political cohesion of the Irish-American community is illustrated by its treatment of one who broke from its ranks. In order to fully appreciate his situation and its significance, however, one must look to the Irish immigration of the $1840 \mathrm{~s}$, the interaction between American society and these newcomers, and the subsequent political effects thereof.

The potato rot which struck Ireland in 1845 caused great famine in an already impoverished land and stimulated emigration, especially to the United States. Prior to 1840 the number of immigrants landing in Boston reached four thousand only once, and most of the newcomers were westward-bound. However, by 1850 the Irish population in Boston had grown to thirty-five thousand, and swelled past fifty thousand by $1855 .{ }^{11}$ These impoverished Irish immigrants needed immediate employment upon landing in Boston, a condition that precluded the luxury of choosing a job or learning a trade. General aversion toward hiring the Irish except for manual work, coupled with their lack of capital, literacy, or skills, led the newcomers to rely heavily on unskilled positions. ${ }^{12}$

These Irish-Americans spurred Boston's industrial growth by providing a cheap labor pool, and the number of industrial employers doubled in the decade between 1845 and 1855 and again from 1855 to 1865 . The textile industry flourished, aided by the availability of immigrants willing to learn tailoring and work for wages unacceptable to a proper tailor. While Boston had 473 tailors in 1845 , five years later it had over 1,547 , more than a thou-

\footnotetext{
${ }^{11}$ Handlin, Boston's Immigrants, pp. 45, 51-52.

${ }^{12}$ Edward M. Levine, The Irish and Irish Politicians (Notre Dame: University of Notre Dame Press, 1966), pp. 58-59. Handlin, Boston's Immigrants, pp. 60, 61.
} 
sand of whom were Irish. When Boston experienced a building boom, Irishmen filled out the construction crews. ${ }^{13}$

Irish-American laborers found both their wages and working conditions to be low, and as more immigrants flowed in there was increased competition for a limited number of jobs. Despite working fifteen-hour days, seven days a week, many workers needed supplementary earnings from their wives, sons, and daughters in order to meet expenses. Initially, even the Civil War did little to ameliorate these conditions, until enough men had been drawn into the army and the industrial stimulation provided by the massive Union war effort created an equilibrium between the supply and the demand for laborers. ${ }^{14}$

Most of the Irish immigrants suffered in terrible living conditions, unable to remove their families to the calm streets and spacious dwellings of suburban Roxbury or Dorchester. Many settled in the clogged North End and Fort Hill slums, where landlords allowed buildings to grow dilapidated rather than make repairs. The Irish took over these sectors and created their own community. Lacking the money to move away, this close contact with their countrymen enticed many subsequent newcomers to gravitate to the stifling tenements. A few Irish-Americans relocated to the South End after the extensions of Washington, Harrison, and Suffolk (Shawmut) Streets and the introduction of horsecars running down to Roxbury in 1856 . However, these were almost wholly limited to educated tradesmen, and Irish representation in the suburbs was limited. Similarly, the opening of street railroads in 1858 made Roxbury more accessible, but only to prosperous groups. ${ }^{15}$

In the North End and Fort Hill districts, people pressed into small rooms and dank cellars. One North End house sheltered a family of nine living in one room, while another had fifteen people in three attic rooms. In Fort Hill, some three- to six-story buildings housed forty to a hundred inhabitants. Putrid air and

${ }^{13}$ Handlin, Boston's Immigrants, pp. 63, 74, 76.

${ }^{14}$ Thomas H. O'Connor, Fitpatrick's Boston 1846-1866 (Boston: Northeastern University Press, 1984), p. 83. Handlin, Boston's Immigrants, pp. 61, 86.

${ }^{15}$ As early as 1850 , 40 percent of Roxbury's population were foreigners or children of foreigners; however, they were primarily non-Irish immigrants. Handlin, Boston's Immigrants, pp. 91, 93-94, 99. Levine, The Irish and Irish Politicians, p. 58. 
contaminated, undrained water fostered diseases such as cholera, smallpox, dysentery, and consumption in epidemic proportions. The unsanitary conditions led to a high mortality rate among children, who suffered high incidence of pneumonia, bronchitis, and intestinal disorders. ${ }^{16}$

The hard labor and low quality of life led to great indulgence in alcohol. In 1846 there were 850 liquor dealers in Boston; by $1849,1,200$ bars existed in the city. By 1850 , Irish-Americans operated 900 of 1,500 such establishments, and a survey conducted by the city marshal in November 1851 found that nearly half of Boston's groggeries were concentrated in the North End and Fort Hill districts. Such places were popular for their cheap whiskey, for providing an opportunity for people to gather and socialize, and as centers of political activity. ${ }^{17}$

The Democratic party of the 1850s supported unrestricted immigration and freedom from interference in religious and social concerns. Democrats attacked what they viewed as a Republican attempt to intervene in all facets of life: nativist limits on immigration, the restriction of individual and collective ethnic conduct found to be incompatible with their views, and the violation of personal liberty by state intrusion into people's conduct and beliefs. The Republicans were seen as attempting to impose their puritanical beliefs on everyone by attacking Catholicism, tampering with slavery, and promoting prohibition of alcohol. ${ }^{18}$

The Irish turned out as staunch supporters of the Democrats and remained hostile to the reform impulses that evolved into the Republican party. Such movements as the nativist hostility toward immigrants, pro-temperance activism, and abolitionism were partly the manifestation of northern, native-born Protestants' fears. Their notion of moral stewardship joined with a view that the state should have wide authority to direct the economic life

${ }^{16}$ Robert H. Lord, John E. Sexton, and Edward T. Harrington, History of the Archdiocese of Boston 3 vols. (New York: Sheed \& Ward, 1944), 2: 453-54. Handlin, Boston's Immigrants, p. 115. O'Connor, Fitzpatrick's Boston, p. 84.

${ }^{17}$ Dennis P. Ryan, Beyond the Ballot Box: A Social History of the Boston Irish, 1845 1917 (Rutherford, N.J.: Fairleigh Dickinson University Press, 1983), p. 85. Thomas H. O'Connor, The Boston Irish: A Political History (Boston: Northeastern University Press, 1995), p. 65. Handlin, Boston's Immigrants, p. 121.

${ }^{18} \mathrm{Joel} \mathrm{H}$. Silbey, A Respectable Minority: The Democratic Party in the Civil War Era 1860-1868 (New York: W. W. Norton, 1977), pp. 24-25. 
of the country. Abhorrence of Rome, the papacy, and Catholics unified the Protestants against Irish immigrants and led to a nativist demand that ethnic groups renounce both their cultural roots and their clannishness, though not necessarily their values, in order to assimilate into American Anglo-Saxon culture. ${ }^{19}$

Some Protestant Yankees, observing Catholics arriving on their shores, felt fear and animosity toward these Europeans and their foreign culture and religion. The Irish maintained particularly strong ties to their old country and a close sense of community in their adopted land, and this reinforced nativist hostility toward the newcomers. Concern over Irish-American loyalty to foreign religious leaders such as the pope, their strong interest in events in their mother country, and clamors for United States involvement in Ireland's quest for independence strengthened such Yankee perceptions. ${ }^{20}$ The Democrats absorbed these immigrants, especially in urban areas, while many Northern Protestants abandoned the party in favor of the nativist American, or Know-Nothing, party. These rejectionists felt the Democrats had grown unconcerned of the immigrant threat, or worse, welcomed them as a source of new votes. Not surprisingly, Protestant groups less affected by the Catholic influx remained more loyal to the Democratic party. ${ }^{21}$

A number of Radical Republicans opposed the nativist wing of the party, viewing it as preoccupied with a minor issue which detracted from the principal mission of the party, combatting slavery. The editor of the radical National Era, Gamaliel Bailey, attacked Know Nothingism as irreconcilable with civil and religious liberty. While content for nativists to cast their ballots for Republican candidates, William $\mathrm{H}$. Seward remained unwilling to make concessions on abolitionism or the rights of foreigners in

\footnotetext{
${ }^{19}$ Eric Foner, Free Soil, Free Labor, Free Men The Ideology of the Republican Party Before the Civil War (New York: Oxford University Press, reprint 1995), pp. 22729. The question of Cuba's annexation serves to illustrate this loathing of Catholicism. John P. Hale and other Republicans opposed it not only on an antislavery motivation, but on the grounds that most of Cuba's population was Catholic, while the United States was rooted in and maintained on the principles of Anglo-Saxon Protestants.

${ }^{20}$ O'Connor, The Boston Irish, pp. 69-70. Levine, The Irish and Irish Politicians, p. 63.

${ }^{21}$ Silbey, A Respectable Minority, pp. 15, 17.
} 
order to gain their votes. Nonetheless, while the 1856 Republican platform did not support nativism the party was still associated with the movement. ${ }^{22}$

The Irish resented governmental attempts to control alcohol consumption. Even while trying to cope with the problems of drunkenness in the Irish-American community, the Catholic Church opposed state interference in this matter. Religious fervor permeated the prohibitionists, who, deeming drinking to be impious and contrary to God, tried to use government to "annihilate sin." The first prohibition law passed in Maine in 1851, but by 1855 the Democrats recaptured control of that state's legislature by capitalizing on ethnic hostility against another similar act passed by the Republican legislature elected a year earlier. Elsewhere, temperance movements met with such opposition that state Republican parties stopped discussing the issue. ${ }^{23}$ Meanwhile, some reformers blamed the Irish for the failure of the Maine acts and, linking the Irish and their religion to the vice of drinking, vowed to oppose Catholicism. ${ }^{24}$

A variety of reasons led Irish-Americans to maintain hostility to both abolitionists and their cause. The Irish felt dismay at the prospect of millions of freed slaves migrating north, intensifying competition for already scarce jobs and driving out white laborers. ${ }^{25}$ During the Civil War, The Pilot, an influential Boston newspaper that served the city's Irish population, questioned,

... where the white find it difficult to earn a subsistence, what right

has the negro to either preference, or to equality, or to admission?

${ }^{22}$ Foner, Free Soil, Free Labor, Free Men, pp. 233-35, 249. William Seward became popular with the Irish because of his position on financial aid to Catholic schools while governor of New York. In January 1840 he began a two-year controversy by proposing to give some funding to the schools, but the money was never appropriated. He later served as Secretary of State under Presidents Abraham Lincoln and Andrew Johnson. Florence E. Gibson, The Attitudes of the New York Irish Toward State and National Affairs 1848-1892 (New York: Columbia University Press, 1951), p. 106.

${ }^{23}$ Massachusetts Anti-Liquor Law; with an Analysis and Exposition (Boston: State Temperance Committee, 1852). Address of the State Temperance Committee to the Citizens of Massachusetts on the Operation of the Anti-Liquor Law (Boston, 1853). Foner, Free Soil, Free Labor, Free Men, pp. 241-42. Handlin, Boston's Immigrants, p. 134.

${ }^{24}$ Levine, The Irish and Irish Politicians, p. 93.

${ }^{25}$ The Pilot, July 20, 1861; February 15, 1862. Handlin, Boston's Immigrants, p. 133. Ryan, Beyond the Ballot Box, p. 130. The July 20, 1861 edition of The Pilot 
... What has the African done for America? What great or even decent work has his head conceived, or his hands executed? We pity his condition; but it is unjust to put him in the balance with the white laborer. To white toil this nation owes everything; but to black, nothing. ${ }^{26}$

Amidst the scorn aimed at them, the Irish could find solace in the existence of a social class beneath them. Living in the slums of Boston themselves, Irish-Americans viewed blacks not with fraternal sentiments as another oppressed group, but as a peril to their jobs. ${ }^{27}$ Many blacks, in turn, felt hostility toward the Irish, as immigrants drove free African-Americans out of the job market. While blacks composed the majority of servants in New York City in 1830, two decades later the number of Irish domestics alone outnumbered the city's total black population ten to one. These African-Americans, angered at losing their jobs, derisively referred to the Irish as "white niggers." 28

When the Irish patriot Daniel O'Connell urged his countrymen in America to oppose slavery in the interest of liberty, many IrishAmericans attacked his stance and argued that their obtaining equality with Protestant Yankees took priority. Irish in both America and Ireland adored O'Connell, who had participated in the antislavery activism which resulted in England's emancipation of slaves in the British West Indies. On May 9, 1843, O'Connell gave a speech in Dublin in which he attacked slavery as a "black spot" and a "damning stain," a crime which "a just Providence will sooner or later avenge." Irish-Americans resented these remarks, as well as a subsequent petition he addressed to them urging their opposition to slavery; The Pilot criticized O'Connell's interference with a domestic issue. ${ }^{29}$

emphatically declared, "The white men of the free states do not wish to labor side by side with the Negro."

${ }^{26}$ The Pilot, August 16, 1862.

${ }^{27}$ Levine, The Irish and Irish Politicians, p. 60. O'Connor, The Boston Irish, p. 81. Silbey, A Respectable Minority, p. 82.

${ }^{28}$ Joseph M. Hernon, Jr. Celts, Catholics $\mathcal{E}$ Copperheads (Columbus: Ohio State University Press, 1968), p. 65.

${ }^{29}$ Rice further argues that, due to nativism and anti-Catholic prejudice, IrishAmericans were afraid of being laid open to the charge of European domination. Madeleine Hooke Rice, American Catholic Opinion in the Slavery Controversy (New York: Columbia University Press, 1944), pp. 80-83. Mary Alphonse Frawley, S.S.J., Patrick Donahoe (Washington, D.C.: The Catholic University of America Press, 1946), p. 127. Levine, The Irish and Irish Politicians, p. 96. Hernon, Celts, Catholics $\mathcal{E}$ Copperheads, pp. 59-61. 
While insisting that slaveowners treat their slaves justly and charitably, the Catholic Church did not find the institution contrary to divine or natural law. ${ }^{30}$ Madeleine Hooke Rice found that "Ecclesiastical leaders, mindful of conflicts between church and civil authorities in the Old World, were fearful of tendencies toward greater centralization of governmental powers in the United States. Convinced that slavery was a matter of local concern, they quite generally advocated state rather than federal control.", 31

The anti-Catholic stance of most abolitionists, partially motivated by the immigrants' pro-slavery bias, further insured IrishAmerican hostility to the movement. As early as 1839, The Pilot warned that many abolitionists were "bigoted and persecuting religionists ... [desiring] the extermination of Catholics by fire and sword." ${ }^{32}$ Abolitionist goals and strategy, such as that preached by William Lloyd Garrison, were viewed as a threat to the nation's safety and adverse to Irish values. The Pilot reported to a Catholic population which already saw abolitionists as opponents of religion, public order, and the Union. Freesoilers, also known as Black Republicans, were seen as being in "direct conflict with the Constitution." 33

Irish views on temperance and abolitionism furthered nativist hostility, which was exacerbated by their dramatic expansion as part of the voting population. From 1850 to 1855 , the Irish accounted for almost half of the total increase in Massachusetts' population, and while the native-born vote grew 14.7 percent, the foreign-born vote, comprised mostly of Irish, exploded at 194.6 percent. ${ }^{34}$ Extreme nativists in the 1855 Massachusetts legislature moved to exclude foreigners from voting or office-holding rights completely. The state's Know-Nothing governor, Henry Gardner, proposed a twenty-one-year period following naturalization before newcomers could receive suffrage. The legislature adopted

\footnotetext{
${ }^{30}$ Hernon, Celts, Catholics $\mathcal{E}^{\circ}$ Copperheads, p. 66.

${ }^{31}$ Rice, American Catholic Opinion in the Slavery Controversy, p. 114.

${ }^{32}$ The Pilot, September 23, 1839.

${ }^{33}$ Hernon, Celts, Catholics $\mathcal{E}^{2}$ Copperheads, p. 59. Ryan, Beyond the Ballot Box, p. 130. Rice, American Catholic Opinion in the Slavery Controversy 2 pp. 78, 93, 95, 109. The Pilot, May 31, 1856, quoted in Rice, p. 95.

${ }^{34}$ Nonetheless, a lack of leadership, funding, and organized political machines at this point prevented Irish-Americans from fully taking advantage of their electoral power. O'Connor, The Boston Irish, p. 70.
} 
this measure, along with acts mandating a literacy test for voting and the disbandment of foreign militia companies. Two more passages were required before the provision became an amendment to the state constitution. The 1856 legislature reduced the waiting period from twenty-one to fourteen years. In 1857, radical Republicans were able to lower the period to two years and the people of Massachusetts voted in favor of the amendment in an 1859 referendum. Additionally, the immigrants' overwhelming support of Democratic urban political machines further fostered Republican antagonism toward them, and some Freesoilers blamed the Irish vote for the defeat of their 1856 presidential candidate, John C. Frémont. ${ }^{35}$

Against nativism and abolitionism, Democrat Stephen Douglas was a heavy favorite of the Irish in the 1860 presidential contest. The New York Irish American endorsed Douglas, and The Pilot expressed the opinion that no Catholic should vote for Lincoln. ${ }^{36}$ Nevertheless, Lincoln and the Republicans emerged victorious and firmly in control of government, at least in the North. By 1860 they controlled fourteen of eighteen governorships above the Mason-Dixon line, 102 of 146 Northern seats in the United States House of Representatives, and twenty-nine of thirty-six Northern seats in the Senate. ${ }^{37}$

Few expected an enthusiastic Irish-American response when Lincoln called for volunteers to help quash the rebellion after the South fired on Fort Sumter. After all, they had opposed Lincoln and denounced reform; they had remained loyal to the Democratic party, and had supported the South and the institution of slavery. However, many Irish in the North remained patriotic citizens of their adopted land, devoted to the Union and to the Constitution that governed it. The Irish American claimed,

For us . . our duty . . . is clear and well-defined. Our standing in this community, the freedom and equality we proudly claim . . . come to us directly from the whole Union, to which our first alle-

${ }^{35}$ A number of Radicals urged total defeat of the suffrage measure, and Republicans in the western United States feared that the measure, if it passed, would hamper efforts to attract German voters to the party. Handlin, Boston's Immigrants, p. 204. Foner, Free Soil, Free Labor, Free Men, pp. 230-31, 250-51. Hernon, Celts, Catholics $\mathcal{E}$ Copperheads, p. 64.

${ }^{36}$ Frawley, Patrick Donahoe, p. 168. O’Connor, Fitzpatrick's Boston, p. 186. Gibson, The Attitudes of the New York Irish, p. 105.

${ }^{37}$ Silbey, A Respectable Minority, p. 18. 
giance is due, under the guarantees of the Constitution which we have sworn to uphold. ${ }^{38}$

Some viewed the war as an opportunity to increase the patriotism of both the populace in general and the Irish-American community in particular, and to reinvigorate the spirit of civic virtue. On November 2, 1861, The Pilot argued,

The war of the North is a just one. . . This same war has already made us love our country better than ever we did before; it will correct the corruption of all our political proceedings; and at the end of it we shall be contupled in spirit and in ability to defend the integrity of the Republic against any foe. ${ }^{39}$

The Catholic Church's emphasis that government must be lawfully established helped preclude Irish-American support of the illegitimate government of the Southern revolt against the Constitution. Furthermore, England's pro-Confederate sentiments antagonized Irish support for the Rebels. When the Trent affair erupted in late 1861, caused by Federal Captain Charles Wilkes's forcible removal of Confederate envoys from the British ship, the Irish American welcomed the prospect of war with Britain. Similarly, some members of the Irish Brigade embraced the possibility of conflict and greeted the news "[w]ith a wild and joyous feeling," imagining Irish exiles envisioning "the revivification of 'Erin, our mother and discrowned queen.' "' 40 Of course, sectionalism played a major role in determining loyalties, and many a Southern Irishman served in the Confederate ranks during the war.

The Irish Charitable Society unanimously adopted resolutions denouncing any "principle or movement that would dissever these United States" and, after affirming their "love for the Union and Constitution," summoned all Irish to support the

\footnotetext{
${ }^{38}$ Irish American, April 20, 1861.

39 The Pilot, November 2, 1861.

${ }^{40}$ The Pilot (June 8, 1861) printed: "When England takes part with the South, she can have no possible good object in view. . . . When we Irish are side by side with England in any quarrel, we must be in the wrong. It is the natural instinct of our race to hate the English side, and take the other; and if the southern States of America have England for their backer, they must look on it as a thing of fate to have Ireland for their foe." The Pilot, October 26, 1861. Irish American, January 11, 1862. Handlin, Boston's Immigrants, pp. 208-209. O'Connor, Fitzpatrick's Boston, p. 187.
} 
Union regardless of sectional preferences. ${ }^{41}$ Following the bombardment of Fort Sumter, Irish-American newspapers announced their support of the Union. While criticizing Northern fanatics for antagonizing the South, the Irish American argued that secession was unjustifiable and called upon its readers to support the Union. The Pilot announced in January 1861 that "Catholics have only one course to adopt, only one line to follow. Stand by the Union; fight for the Union; die for the Union." ${ }_{42}$

Nevertheless, articles in The Pilot consistently stressed that Irish volunteers went forth in support of the Union and not to free the slaves. The July 20, 1861 edition of the newspaper declared that "Not one volunteer in a hundred has gone forth . . . to liberate slaves." ${ }_{43}$ In the summer of 1862 the anti-black feelings of the Irish-Americans erupted into riots in several cities; for example, two to three thousand Irishmen assaulted blacks in Brooklyn on August 4, 1862. ${ }^{44}$

The Emancipation Proclamation created a maelstrom of Irish hostility toward Lincoln and the Republican party. The Pilot assessed the administration as "incompetent, fanatic, radical" and noted widespread Irish sentiments that Lincoln had betrayed them to the anti-Catholic abolitionist movement. According to The Pilot, Emancipation would harden the Southern will to fight, postpone the war's conclusion, and result in hordes of freed blacks streaming north to take jobs from white laborers. The newspaper proclaimed in May 1863 that "the Irish spirit for the war is dead!" and, in September, observed that "At one time we did support Lincoln ... he changed, and so have we." The New York Irish American concurred, condemning the Emancipation as giving "to the South the strongest incentive to fight with greater desperation than ever" and stating that it signified Lincoln's surrender to radical abolitionism. ${ }^{45}$

\footnotetext{
${ }^{41}$ Cullen, The Story of the Irish in Boston, p. 32.

42 Irish American, November 17, 1860. The Pilot, January 1, 1861. The Pilot concurred that "fanaticism for the negro compelled the South to revolt. ..." The Pilot, April 4, 1863.

${ }^{43}$ The Pilot further asserted, "The white men of the free states do not wish to labor side by side with the negro."

${ }^{44}$ Hernon, Celts, Catholics $\mathcal{E}^{2}$ Copperheads, p. 19.

${ }^{45}$ The Pilot, October 4, 1862; December 13, 1862; January 17, 1863; May 30, 1863; September 19, 1863. Irish American, January 10, 1863, quoted in Gibson, The Attitudes of the New York Irish, pp. 142-43.
} 
The Pilot supported Major General George B. McClellan as the Democratic candidate for President in 1864. According to the paper, Lincoln was alternately a "boob" or a cunning Mephistopheles. Only if the Democrats captured the White House could the restoration of the Union be achieved, as they would not be vindictive in accepting the South's return. The Pilot further argued that "the Democratic party ... has been . . . the only hope and refuge to which the oppressed of Ireland could flee" and claimed, "the opposition . . . has distinguished itself by . . . its narrow bigotry ... and its open hatred for the rights of the poor and laboring classes." While the Irish American did not support the peace movement, it endorsed McClellan in August and went so far as to deem him "the most untrammelled candidate ever presented, on an unblemished record ... his only Mentors the voices of the Fathers of the Republic. ..." ${ }^{46}$ Dale Baum calculated that Massachusetts Irish-Americans "preferred McClellan to Lincoln at a rate of nine to one." While Irish-born voters comprised 10 percent of the Massachusetts electorate in 1864, they provided 37 percent of McClellan's vote versus a mere 2 percent for Lincoln. ${ }^{47}$

Guiney greatly differed from the majority of Irish by supporting Lincoln and the causes for which he stood. As early as September 1861 Guiney repudiated his support of the Democrats and wrote, "The sordid misers who are not accumulating in these novel times, and the craven Democrats who rot in office and starve out of it, are trying all over the country to get up an opposition to the government." 48

Furthermore, Guiney realized the wrongs of slavery and agreed in principle with the abolitionists. In July 1861 he wrote his wife that "slavery curses the land in which it is." 49 Near Big Bethel, Virginia, at the end of March 1862, five black females entered

${ }^{46}$ The Pilot, June 25, 1864; September 3, 1864; October 15, 1864; and November 5, 1864, quoted in O'Connor, Fitzpatrick's Boston, p. 209. Gibson, The Attitudes of the New York Irish, p. 165. Irish American, November 12, 1864. The November 12 edition was distributed in advance of its usual time, so as to reach people before the November 8 election.

${ }^{47}$ Dale Baum, "The 'Irish Vote' and Party Politics in Massachusetts, 18601871," Civil War History, vol. 26, no. 2 (March 1980), 122.

${ }^{48}$ Patrick R. Guiney to Jennie Guiney, Arlington Heights, Va., September 1st, 1861.

${ }^{49}$ Patrick R. Guiney to Jennie Guiney, Washington, D.C., July 14, 1861. 
the Ninth's picket line while Guiney was on duty and he proudly proclaimed, "In the name of old Ireland and Massachusetts, I set you free." In thanking a company that presented him with a sword in late August 1862, Guiney mentioned "Irish devotion to the vindication and establishment of human liberty," presumably for both Irish-Americans and the slaves. In a speech supporting Ulysses S. Grant's candidacy for president in 1868, Guiney said that the "seething despotism ... of human slavery was menacing and shaking this Republic ... " before the Civil War erupted. ${ }^{50}$

Guiney openly expressed his sentiments, and these political views and support for Lincoln caused him trouble within the Ninth Massachusetts. By February 1863 a saddened Guiney wrote, "I find but very few whose views are congenial to me. I am weary of expressing my opinions. I would like to serve on to the end-to the triumphant end-but how painful in the midst of men who are constantly talking down the government!" ${ }_{51}$ While campaigning for Lincoln during the 1864 election, Guiney admitted, "the great bulk of my countrymen differ with me in politics, as they have a perfect right to do, and I differ with them, as I have an equally perfect right to do. ..." After the war, Guiney noted in a speech, "During the war I held opinions and spoke them on public matters, as you well know. These opinions did me no good at the time. Indeed, they were not agreeable to my dearest friends, as I had occasion to know." 52

Several incidents illustrate the hostility some Irish-Americans felt at Guiney's political outspokenness, as well as the jealousy occasioned by his swift rise to command. The most serious occurred when, upon assuming command of the regiment following Cass's death, Guiney faced a conspiracy of eleven officers who designed to replace him with another. The clique sent a petition to Governor Andrew criticizing Guiney for his absence from the battle of Malvern Hill on July 1, 1862. They ignored the fact that, at the time, Guiney was extremely ill with malaria which rendered

\footnotetext{
${ }^{50}$ The Pilot, April 26, 1862; September 13, 1862. Draft of one of Guiney's speeches in support of Ulysses S. Grant and written in Guiney's hand, located in the Rare Book Room of Dinand Library, College of the Holy Cross.

${ }^{51}$ Patrick R. Guiney to Jennie Guiney, Head Quarters 2nd Brigade, February $11,1863$.

${ }^{52}$ Patrick R. Guiney to Editor of the Boston Journal, Boston, September 27, 1864 in Guiney scrapbook, 3. Guiney scrapbook, 10, 13.
} 
him unable to move without help and confined him to an ambulance. One newspaper noted, "Col. Guiney, being a gentleman as well as a soldier, was outside of a certain grog-house ring at the North End of Boston, which undertook to control the regiment. These men fomented dissatisfaction among the officers and finally induced eleven of them to bring charges against Col. Guiney, the substance of which was that he was 'suddenly taken ill' before the battle of Malvern Hill. ..." In 1864, when Guiney campaigned in support of Lincoln's re-election bid, the issue was resurrected in retaliation. The article's defense of the colonel continued: "Guiney's only sin is that he unites with nine out of ten of the soldiers of our army and the great bulk of the loyal population of the North in advocating the election of President Lincoln. For this, those worn-out lies are paraded again in the columns of the [Boston] Courier." ${ }_{53}$

The North End slum, as a Democratic stronghold, proved to be troublesome to Guiney in this incident and throughout the war. The petitioners' ringleader, Captain Timothy O'Leary, was a resident of Salem, but he had close ties to the North End; in February 1863 his friends there gave O'Leary a sword and belt. ${ }^{54}$ People associated with the North End continually antagonized Guiney throughout the war with public criticism, letters to Governor Andrew, and general disdain. For example, in the spring of 1863 Guiney disciplined two non-commissioned officers for absence without leave by reducing their rank, putting them in the guard house for a night, and having them tied for a day, labelled "skulker." North-Ender Eneas Smyth retaliated by requesting various inquiries of this action and by penning a vicious assault on the Ninth Massachusetts' commander, in which he deemed Guiney a "political and skedaddling Colonel." Guiney wrote that "the unarmed traitors of the North End encourage them [i.e., officers opposing him] in seeing hostility to me because I am for the government in all its measures-and they know that I am." Guiney further recognized the slum as a stronghold of the Copperhead movement, which opposed Lincoln and prosecution of the war, advocating a compromised peace instead..$^{55}$

${ }^{53}$ Guiney scrapbook, 11-12.

${ }^{54}$ The Pilot, February 21, 1863. Guiney scrapbook, 2.

${ }^{55}$ Boston Post, April 17, 1863. Patrick R. Guiney to Jennie Guiney, Head Quarters 2nd Brigade, February 26, 1863. Patrick R. Guiney to Jennie Guiney, LogHouse at Camp, April 13, 1863. 
There were also socioeconomic factors in this situation. Dennis P. Ryan wrote that "Irish students who matriculated from Boston College, Holy Cross College in Worcester, or Harvard were an unusually ambitious lot." In addition, many Irish-Americans living in the slums and tenements of the North End and Fort Hill districts felt hostility toward those who moved upward.$^{56}$ Guiney arrived in America before the mass immigration of the famine Irish which started in 1845 . Although financial reasons prevented his graduation from Holy Cross, Guiney did become a lawyer successful enough to move to the Roxbury suburbs and to enjoy membership in the Irish Charitable Society. Among the underprivileged as a youth, Guiney had achieved a measure of success and wealth which eluded most Irish-Americans. He looked down on lower-class behavior and wrote in 1862, "What do I care for a drunken rabble?" ${ }_{57}$ Guiney's status as an educated lawyer gave him job security, and no reason to fear the emancipation of the slaves. The coupling of his intellectual enlightenment and his economic condition directly resulted in Guiney's political views. This no doubt antagonized members of the North End already angered by Guiney's political sentiments. ${ }^{58}$

Another complication came from the intrigues of officers and outsiders seeking to control advancement within the regiment, something which greatly bothered Guiney. Boston Irish leaders such as Patrick Donahoe and Bernard S. Treanor sought to pro-

\footnotetext{
${ }^{56}$ Ryan, Beyond the Ballot Box, p. 73. Levine, The Irish and Irish Politicians, p. 103.

${ }^{57}$ Patrick R. Guiney to Jennie Guiney, Head Quarters 9th Massachusetts, November $30,1862$.

${ }^{58}$ The professions of those who petitioned Governor Andrew following Guiney's promotion indicate that social and economic differences worsened the tensions between him and the other officers. Of the nine signers whose occupations are known at the time of mustering in, only one, a law student, was involved in professional work. Among the other jobs held by members of the clique were bootmaker, tanner, blindmaker, shoemaker, clerk, custom house worker, and gasfitter; ringleader Timothy O'Leary was a tailor. Similarly, two other chronic troublemakers for Guiney, Captains James F. McGunnigle and John C. Willey, were a bootmaker and a turnkey, respectively. On the other hand, one of his earliest friends in the regiment was a professional, a physician named Edward Fitzgerald. See the muster roll printed in Daniel George Macnamara, The History of the Ninth Regiment Massachusetts Volunteer Infantry (Boston: E. B. Stillings \& Company, 1899). Hereafter cited as Macnamara, Ninth Regiment. See also Massachusetts Soldiers, Sailors, and Marines in the Civil War, and Marines in the Civil War 8 vols. and index, compiled and published by the Adjutant General of Massachusetts, 1931-1937. Information on the Ninth Massachusetts is available in volume 1.
} 
mote their candidates for various commissions. Timothy Regan, a member of the Ninth Massachusetts, wrote in his diary that "not always has merit had anything to do with ... promotions, the influence of friends at home being 'the power behind the throne." " ${ }_{59}$ Officers within the regiment tried to engineer promotions for their cronies as well. Regan noted, "I am satisfied that the Colonel is not to blame, but that it is the doings of some of the captains who send for their friends to join the companies with a view of promoting them to be noncommissioned officers, and then to engineer them into lieutenancies." 60

Guiney may have felt wearied and troubled that his political views led to personal attacks against him. Nonetheless, he remained unbowed and continued in his outspoken support of the cause for which he fought and of its leader, Abraham Lincoln. While at home soon after receiving his horrible head wound at the Wilderness, Guiney gave a speech at a pro-Lincoln rally of Union supporters in Roxbury before the 1864 election. The meeting convened at a packed Institute Hall in Roxbury, and throngs waited outside in a vain attempt to gain admission. Upon Guiney's introduction, a number of Democrats present began hissing to show their disfavor of his views, but the audience drowned out the disrupters with three ringing cheers for Guiney and a round of applause. Some wanted to eject the protesters, but Guiney asked them not to touch the offenders. He continued with his speech, stating that he once felt proud to be a Democrat but could not support them under traitorous leaders. Guiney also remarked that Stephen Douglas, so popular among Irish-Americans

${ }^{59}$ Timothy J. Regan diary, January 28, 1862. Hereafter cited as Regan diary. William L. Burton, Melting Pot Soldiers: The Union's Ethnic Regiments (Ames: Iowa State University Press, 1988), pp. 131-35. An example of this meddling came during the formation of the second Massachusetts Irish regiment. Patrick Donahoe supported Francis Parker for its commander while Bernard S. Treanor criticized Donohoe's choice, and claimed that he could submit the name of a gentleman from among 25 Irish nationalists. Irishmen from New York contacted Governor Andrew with their opinion that he should staff the regiment with New York Irish and push to get it attached to Brigadier General Thomas F. Meagher's Irish Brigade. Andrew announced plans for two new Irish regiments, one of which could go to the Irish Brigade, in an effort to placate the various parties. The Twenty-eighth and Twenty-ninth Massachusetts Infantry Regiments went to New Yorkers William Montieth and Thomas J. Murphy, respectively, and Andrew soothed a dissappointed Parker by assigning him command of the Thirty-second Massachusetts.

${ }^{60}$ Regan diary, October 26, 1862. 
in the 1860 election, would have supported the present government. He then quoted Irish hero Daniel O'Connell's loathing of slavery. Concluding with a critical recounting of McClellan's military career, he received thunderous applause for his speech. ${ }^{61}$

Soon afterward, Guiney gave a similar oration at Dorchester on October 4, 1864. He happily noted that here, men were "allowed to come forward with their voices for the Union and speak in peace and without disturbance." Guiney then attacked slavery as an evil which "simmered, and burned into the very vitals of the nation, until, at last, it raised up armies to fight against our Republic," and deemed it the "strength of the rebellion." He again invoked O'Connell's opposition to slavery and reviewed McClellan's military record, criticizing his waste of time in sieges (referring to Yorktown) and blaming his slowness for the Second Manassas debacle. McClellan and the Democrats, Guiney said, desired no more than the restoration of the Union, while Republicans wanted to combat those who perpetrated "a great crime against the human race." He also said that any man who acted to weaken the government "will have committed a crime for which a life of penance cannot expiate." ${ }^{62}$

After the war, Guiney maintained that he "was the only member of that regiment [the Ninth Massachusetts] who called himself a Republican." 63 The issue of his support of Lincoln followed him as well. In late 1866, an article in The Pilot called the Colonel a "high-minded, honorable man," but also noted "He opposed General McClellan, which we are sorry for. . .."64

Guiney's situation, that of an enlightened and educated Irishmen holding political views different from the bulk of his countrymen, parallels that of Thomas Francis Meagher. A New York lawyer, Meagher became a popular lecturer. He was the only Irishman of national prominence to support the Lincoln administration in the 1864 election, a stance that seriously crippled his popularity among the Irish community. American Catholics called him a "Red Republican," a term used for those committed to promoting atheism and disrupting social order, morality and

\footnotetext{
${ }^{61}$ Guiney scrapbook, 2.

${ }^{62}$ Daily Advertiser, October 7, 1864 in Guiney scrapbook, 12-13.

${ }^{63}$ Guiney scrapbook, 10.

${ }^{64}$ The Pilot, October 13, 1866.
} 
religion. ${ }^{65}$ Guiney and Meagher shared a friendship, no doubt largely based and sustained on their similar political views. Included in this volume is a telling letter from Meagher to Guiney, in which Meagher unleashed a scathing criticism of the Democratic party and of the Irish who blindly followed its traitorous course. Several ethnic periodicals published the letter and fiercely attacked its author. The Irish American criticized his "uncalled for and unwarranted attack upon our countrymen" and wrote of Meagher, "It is not an enviable position for one for whom a better fate might have been hoped; but it is of his own choosing. ... [B] etween him and the people who loved and trusted him once he has opened a gulf he never can bridge over." Another edition lamented a pro-Lincoln speech he gave:

In General Meagher's fall from the high position he once held in the esteem and affection of his countrymen, we see only a subject for regret; our indignation at his unprovoked attack upon our people has long since subsided into contempt, and we have no desire to add a deeper tint to an act that has gone so far to darken the record of a life, of which the promise was once so fair. ${ }^{66}$

Guiney did not suffer such a fate. After the war, he maintained a prominent position among the Irish-American community and participated in political events. However, that is a matter to be discussed in the epilogue of this book. First, here are his lettersthe writings of a civilian at war and an officer in command. They reveal not only the experiences and thoughts of a Boston Irish Catholic soldier, but also the hidden tensions within that immigrant community. Guiney's significant views and observations not only illuminate his personal independence of thought, but also the political landscape which he tried to improve.

\footnotetext{
${ }^{65}$ Hernon, Celts, Catholics $\mathcal{E}$ Copperheads, pp. 105-106. Rice, American Catholic Opinion in the Slavery Controversy, p. 91.

${ }^{66}$ Thomas Francis Meagher to Patrick R. Guiney, New York, October 7, 1863. Irish American, October 15, 1864; November 12, 1864.
} 